\title{
Editorial \\ Unraveling the Diversity of Trajectories and Drivers of Global Agricultural Land Abandonment
}

\author{
Alexander V. Prishchepov ${ }^{1, * \mathbb{C}}$, Florian Schierhorn ${ }^{2}$ and Fabian Löw ${ }^{3}$ \\ 1 Department of Geosciences and Natural Resource Management (IGN), University of Copenhagen, \\ Øster Voldgade 10, DK-1350 København K, Denmark \\ 2 Leibniz Institute of Agricultural Development in Transition Economies (IAMO), Theodor-Lieser-Str. 2, \\ 06120 Halle (Saale), Germany; schierhorn@iamo.de \\ 3 MapTailor Geospatial Consulting GbR, Nassestrasse 13, 53113 Bonn, Germany; fabian.loew@posteo.net \\ * Correspondence: alpr@ign.ku.dk or prialign@gmail.com
}

check for

updates

Citation: Prishchepov, A.V.; Schierhorn, F.; Löw, F. Unraveling the Diversity of Trajectories and Drivers of Global Agricultural Land Abandonment. Land 2021, 10, 97. https://doi.org/10.3390/land10020097

Academic Editor: Andrew C Millington

Received: 5 January 2021

Accepted: 19 January 2021

Published: 22 January 2021

Publisher's Note: MDPI stays neutral with regard to jurisdictional claims in published maps and institutional affiliations.

Copyright: (c) 2021 by the authors. Licensee MDPI, Basel, Switzerland. This article is an open access article distributed under the terms and conditions of the Creative Commons Attribution (CC BY) license (https:// creativecommons.org/licenses/by/ $4.0 /)$.
The world is facing a looming scarcity of land necessary to secure the production of agricultural commodities and experiencing competition from other land uses. Simultaneously, the evidence suggests agricultural land abandonment is widespread globally [1-3], driven by multiple factors, and has strong implications for biodiversity, ecosystem services and human well-being [1-3]. However, the understanding of the patterns, drivers and implications is incomplete and disproportional compared to deforestation studies, despite the widespread land abandonment process. Therefore, this was our motivation to establish a Special Issue (SI) entitled "Agricultural Land Abandonment: Patterns, Drivers and Consequences". We invited papers bringing advances in understanding the patterns and the proximate and underlying drivers of agricultural land abandonment. We specifically encouraged authors to submit papers stemming from human and cultural geography and social science and unraveling the drivers of agricultural land abandonment at the land-use agent level. The Special Issue was run from 2018 to 2020. In total, 11 manuscripts were selected, passed through the in-depth peer review, and finally published, including one review study [4] and two feature papers [5,6]. Overall, the Special Issue achieved the initial objectives, and we learned about new methods for monitoring abandonment $[7,8]$, a complex combination of drivers [4,6,9-12] and future re-use of abandoned lands [6,13]. The authors also enriched our understanding of the social science component related to the process of abandonment and re-use of abandoned lands [5,9,14].

From the geography perspective, there is a great diversity of studies published in our SI. The studies represent abandonment processes in China [12], Myanmar [8], Nepal [4,9,10], Poland [7], Slovakia [6], South Africa [11], Sweden [13] and the United States [5,14] (Figure 1). While agricultural land abandonment is a widespread process in the Global North [15-18], there is now evidence that abandonment is becoming a common landchange phenomenon in the Global South too [4,12,19-21], and our Special Issue confirms so.

\section{The Diversity of Definitions of Agricultural Land Abandonment}

Our SI shows a great diversity of definitions of agricultural land abandonment, not only regarding the thematic definition of the process but also the temporal duration. While these days, agricultural land abandonment $[6,7,14]$, cropland abandonment and farmland abandonment $[9,10]$ are three commonly used terms, a few works indicate that other terms are commonly used too, such as deactivation of farming in South Africa, "deagrarianization", which represents a holistic process of changing the functioning of rural areas and livelihood strategies [11]. However, there are other commonly used traditional terms, such as old fields (in ecology and environmental studies) [22], retired fields (common in the United States, primarily in environmental studies) [23] and post-agrogenic fields (common in the post-Soviet rim, and again, primarily in environmental studies) [24,25] (Figures 2 and 3). 


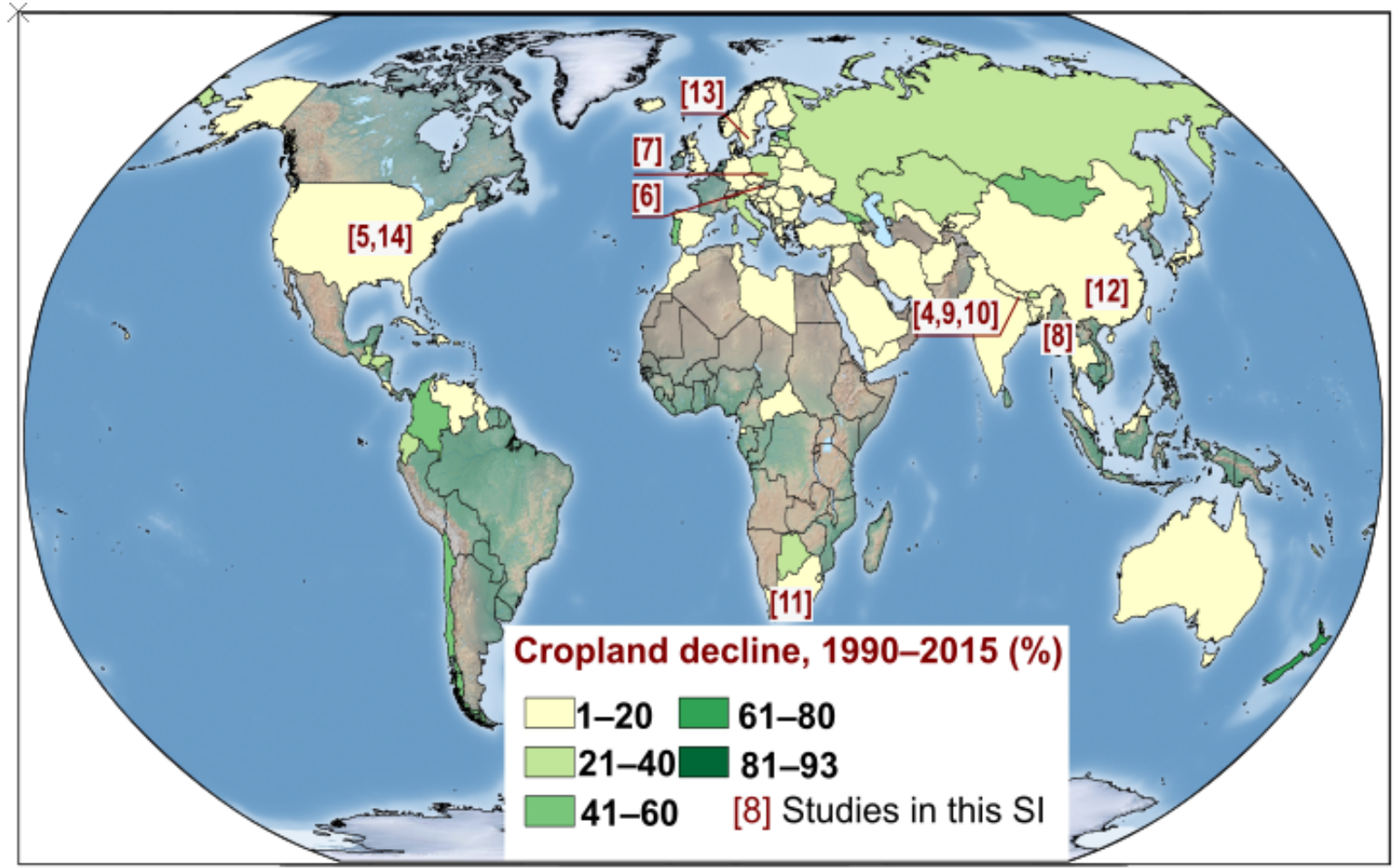

Figure 1. Cropland decline from 1961 to 2015 [26] and the studies published in the current Special Issue.

\section{Frequency}

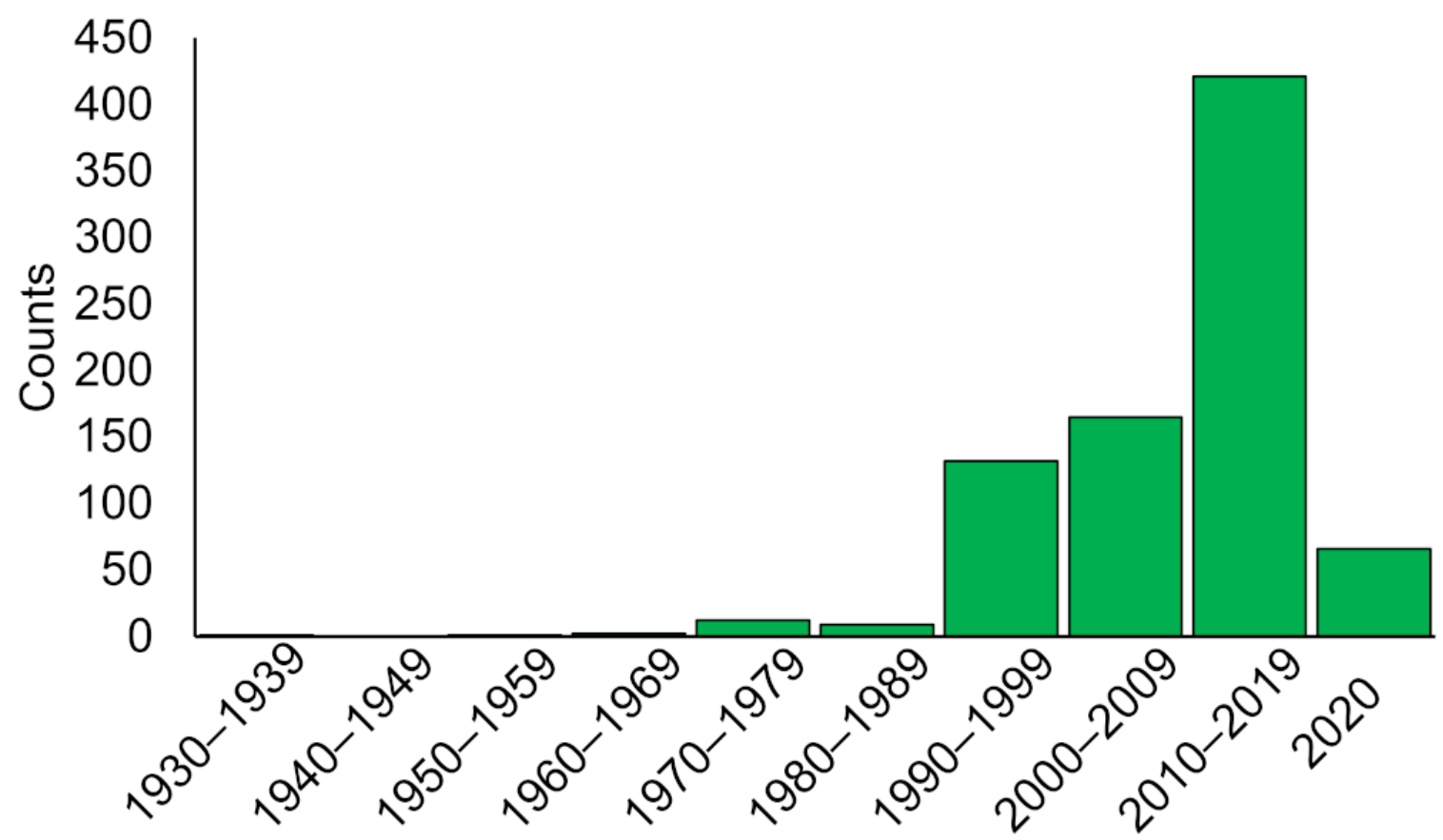

Figure 2. An extended summary of studies based on the systematic literature search in Clarivate Web of Science [1], now with terms agricultural land abandonment, cropland abandonment, old fields, deactivation, deagrarianization, retired fields and post-agrogenic fields/lands.

Agricultural land abandonment can be terminal, incomplete, hidden or reoccurring, and it represents a reduction of farming activities, such as farming intensity over 
time $[9,27,28]$. In this regard, observation of abandonment can be more challenging compared to abrupt land-use changes, such as forest clear-cuts and urban sprawl. There is a commonly used definition of the United Nations Food and Agriculture Organization (FAO), which is the cessation of farming (could be grassland, cropland) and giving away land for nature [29], without signs of management for at least four years [17,30,31]. However, the approaches to defining agricultural land abandonment can stem from different disciplines and utilized sources, such as field surveys, aerial photos, satellite imagery and agricultural statistics, and can depend on the agricultural practices common for the specific territory [5,7,9-11] (Figure 3). The studies published in this SI show that abandonment might result in contrasting trajectories, such as natural succession and vegetation recovery, and land degradation processes [7,9-11]. Therefore, the temporal definition of abandonment, in reality, can vary greatly from the FAO definition. Hence, it is particularly appealing that this SI shows the complexity of understanding land abandonment processes, and this comes in unison with the previous study [31].
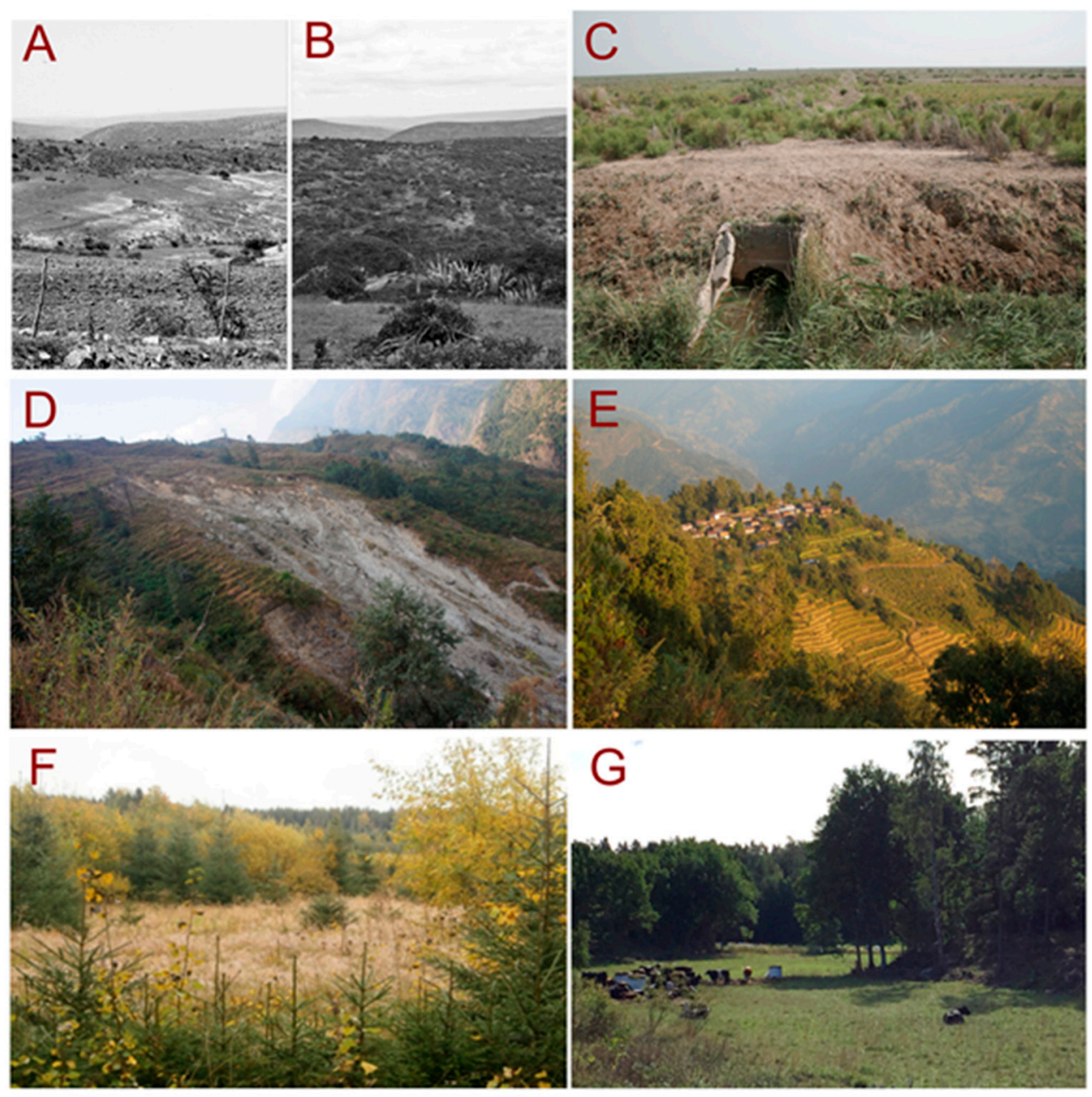

Figure 3. Examples of abandoned fields, including ones covered in the Special Issue. $(\mathbf{A}, \mathbf{B})$ Repetitive photos for the Gawukeni location (former Ciskei, South Africa) in support of [11], photographed by Comins in 1956 (A) and then photographed by Puttick in 2011 (B) (source: repetitive photography project of South African Landscapes http:/ / rephotosa.adu.org.za/Search_photos.php). (C) Example of abandoned fields in Karakalpakstan, Uzbekistan (credit: Fabian Löw) [19]. (D) Degraded abandoned terraces in Nepal; (E) a mix of cultivated and abandoned terraces also in Nepal $[4,9,10]$ (credit: Suresh Chaudhary). (F) Cropland abandonment in Sweden (credit: Karl-Ivar Kumm) [13]. (G) Organic cattle production as an alternative to cropland abandonment in Sweden(credit: Mikaela Jardstedt) [13]. 


\section{The Diversity of Approaches to Document the Patterns of Agricultural Land Abandonment}

The studies published in our SI point toward a great possibility to trace agricultural land abandonment. Earth observation played, probably, the central role in monitoring agricultural land abandonment. For instance, Blair et al. [11] utilized repetitive aerial surveys to reconstruct land change from 1950 to 2010 in South Africa. Chaudhary et al. [10] used unmanned aerial vehicle (UAV) observations to monitor land degradation on abandoned terraces in Nepal. Kolecka and Kozak [7] used a high-resolution vegetation height model (VHM) derived from light detection and ranging (LiDAR) point clouds and topographic data in the Polish Carpathians. Pazúr et al. [6] relied on classified multiseasonal Landsat imagery to obtain the patterns of abandonment in Slovakia. Huang et al. [8] used multisource imagery, employing freely available Sentinel-1 synthetic aperture radar (SAR), optical Sentinel-2 Multispectral Instrument (MSI) and Landsat-8 Operational Land Imager (OLI) products to monitor the decline of cropland intensity in Myanmar. Moreover, a mix of qualitative and quantitative surveys of farmers became useful in assessing ongoing abandonment in China [12], Nepal [9] and the United States [14]. Abandonment can be traced from surveys and statistics as a decline of reported cropland or livestock intensity over time [12]. Holcomb et al. [5] also showed a great utility of human geography ground transects in documenting the abandonment of rural infrastructure in the United States. Several studies employed a mixed analytical approach where either land-change maps were combined with regression techniques $[6,10,11]$ or qualitative and quantitative approaches were used to study the drivers of abandonment and how they are perceived $[9,12,14]$.

The selected approaches to monitor abandonment reflected the sizes of abandoned agricultural fields well. For instance, where agricultural fields are highly fragmented and small, very high-resolution data could be necessary (e.g., in Nepal and the application of UAV [10], Poland and application of LiDAR [7] and parceled fields in former homelands of South Africa and application of aerial photos [11]).

\section{Complex Driving Mechanisms That Result in Agricultural Land Abandonment}

The studies published in this SI show a complex interplay of underlying causes of agricultural land abandonment. The concept of underlying and proximate driving causes of land-use change proposed by Geist and Lambin [32] can serve as a starting point in understanding the driving mechanisms of agricultural land abandonment. Specifically, not only sociodemographic, economic, technological, policy and institutional factors but also cultural factors may drive abandonment. At the same time, predisposing biophysical site conditions and trigger events serve as precursors to agricultural land abandonment. For instance, Blair et al. [11] used repetitive aerial photos and social surveys to show how historical, sociopolitical inequalities evolving from the "post-Apartheid" era, race-based land tenure rights, may have long-standing legacies and implications for agricultural land abandonment in South Africa. Pazúr et al. [6] employed spatially explicit models and revealed how post-socialist transitions and the recent accession to the European Union determined agricultural land abandonment patterns and recultivation in Slovakia. Du et al. [12], based on surveys of households and econometric models, showed the positive role of access of households to formal and informal credits in the reduction of farmland abandonment in China.

In general, rational economic behavior such as profit maximization and increased opportunity costs due to farming explained the process of abandonment well in most cases $[4,6,9]$, such as in cases of abandonment due to outmigration [4-6,9] or abandonment of marginal land $[6,10,12]$. However, other factors appeared as quite novel in terms of understanding the complexity of the abandonment process, including the accessibility to credits for farming and availability of a successor [12], uncertainty regarding expected precipitation [9], change of societal values and living in rural areas on remittances and social grants ("living on land, but not from the land") [11] and risks of being kidnapped and even killed [11]. Thus, these published works on agricultural land abandonment drivers 
fill the existing research gap, promote a better understanding of sociocultural factors and point toward the importance of behavioral science pathways.

This Special Issue contains two distinctive studies on a mix of social and cultural geography. Holcomb et al. [5], with transects, explored signs of abandonment of rural infrastructure and established the archetypes of abandonment in northwest Iowa and central Maine of the United States. The abandonment of rural infrastructure may or may not go hand in hand with the abandonment of agricultural lands. Kuntz et al. [14] revealed dissatisfaction of rural dwellers with ongoing farmland abandonment in New York State in the United States and overall performance of the U.S. economy and local and national regulations, which are supposed to suppress agricultural land abandonment. Such a strong negative perception was particularly prevalent among Republicans. A separate study in this SI points toward a detrimental impact of the ethnic conflict in the Rakhine State of Myanmar and attributes the decline of cropping intensity and partial abandonment of paddy rice fields to this conflict [8]. The study of Huang contributes to the literature on the adverse effects of armed conflicts on land cover and land use [33-36] and underscores the role of triggers and shocks on agricultural systems, echoing findings showing that they often result in agricultural land abandonment [33,37-39].

\section{Trade-Offs between Keeping Agricultural Lands Idle and Alternative Land Uses}

Agricultural land abandonment is a transition process from once-cultivated croplands to natural vegetation with further succession [7] or alternative land uses (e.g., biofuel production, forestry, urban sprawl, leisure) $[27,40]$. There might be both positive and negative impacts of abandonment, not only on biodiversity but also on societal well-being. As published studies showed, abandonment may carry a negative connotation resembling neglecting rural areas [14]. Abandonment can also be perceived from the agriculture-centric perspective when abandoned agricultural land is not a favorable phenomenon and should be, ideally, recultivated and steered [6,9]. However, abandonment is an inevitable process, for instance, in European landscapes. As Kumm and Hessle [13] showed, there has been a steady decline in cultivated lands over the last few decades in Swedish cropland patchwork embedded in forests, and this process will most likely continue in the future. However, this study also showed an alternative to ongoing cropland abandonment and dairy production, as well as proposed forest plantations. For instance, organic beef production of a certain size of the herd can be an option. The re-use of abandoned lands seems to be an interesting topic for future studies, and a qualitative screen of the literature suggests that there is an existing research gap on this topic.

\section{Key Findings and Ways Forward}

Agricultural land abandonment is becoming an evident process in many parts of the world, including the Global South (Figures 1 and 3) [4,8-12]. There is a growing interest among scholars to explore abandonment (Figure 2). Abandonment is a diverse process regarding the trajectories of vegetation recovery in different biomes and intensity of land use. Therefore, there are probably no uniform methods to monitor abandonment at different stages and scales and in different biomes. Hence, further development of a range of methods to monitor abandonment is strongly needed. The driving mechanisms of agricultural land abandonment are quite complex, and participatory social surveys are highly preferential. Institutional factors, such as land governance legacies, may have longstanding effects on land-use agents' decisions and the landscapes in the end. Economic and technological advancements, or their absences, can certainly trigger abandonment. The personal characteristics of farmers play a crucial role in better understanding the driving mechanisms. Overall, and as the studies in this SI show, we are facing ruralurban transition and "deagrarianization" in many parts of the world, which requires revisiting the role of rural landscapes, perhaps with partial agricultural and alternativeto-agricultural re-use and revival of rural areas. The understanding of the complexity of drivers of abandonment would be improved by the conduction of systematic research on 
abandonment at different scales, such as the work completed by the several studies on agricultural land abandonment in Nepal in our SI. While we promoted the submission of studies on a wide range of various aspects of abandonment, the published studies predominantly covered cropland abandonment, while the abandonment of once-managed grasslands, orchards and agricultural and rural infrastructure was not fully presented (with the exception of the work of Holcomb et al. [5]). Therefore, we also encourage future works to fill in the existing thematic gap.

\section{A Short Summary of Studies Published in the Special Issue}

Chaudhary et al. [4] revealed the extent of farmland abandonment in Nepal and provided the qualitative outlook at the existing drivers of farmland abandonment following the concept of proximate and underlying driving causes [32] by careful review of published literature and ancillary data sets.

Holcomb et al. [5] proposed and evaluated a typology with five stages of the contemporary rural landscape transformation in the United States (in memory, end of life, treading water, recycling, renaissance and revival). Following the proposed typology, they conducted transects in northwest Iowa and central Maine. They found a mix of five types of rural transformations, where partial or complete abandonment of settlements goes hand in hand with poverty. However, positive signs of revival were also found to exist, pointing toward "deagrarianization" of rural communities.

Pazúr et al. [6] used classified patterns of agricultural land-cover change from 1986 to 2000 and from 2000 to 2010 and made land-change projections until 2060 in Slovakia. They employed boosted regression trees to assess spatial determinants of agricultural land abandonment and recultivation. The study showed that the spatial patterns and determinants of abandonment and recultivation differed.

Kolecka and Kozak [7] used LiDAR and topographic data and maps of land parcels to evaluate the presence of abandoned parcels with regrowth of young trees and shrubs in the Polish Carpathians. The study showed widespread abandonment with vegetation regrowth; grasslands were more often abandoned than croplands.

Huang et al. [8] used multisource 30-m optical and radar imagery to monitor the conflict-aggravated Rakhine province of Myanmar. The assessment showed one-third of fields in 2016, 2017 and 2018 were fallow, failed or abandoned rice paddies, and this was attributed to the ethnic conflict.

Kc and Race [9] used a mixed-method qualitative and quantitative approach to explore the effect of outmigration in Nepal. They conducted 119 household surveys and 87 indepth semistructured interviews. Descriptive statistics showed a significant presence of underutilized land and a negative influence of not only outmigration but also other factors, such as uncertainty of expected rain.

Chaudhary et al. [10] looked at the spatial-temporal degradation of abandoned terraces previously used for crops in Nepal with the aid of UAV and multivariate regressions. They found that degraded abandoned terraces were prone to bulge. Degraded abandoned croplands were often found on steep slopes and with the presence of grazing.

Blair et al. [11] assessed cropland abandonment from 1950 to 2010 in four former "homelands" in South Africa established during the "Apartheid" time. With the aid of aerial photos, the study revealed that abandonment peaked in the 1970s to the 1990s. A survey of present and past farmers pointed toward a lack of financial means to invest in plowing the land, the perception of droughts as a precursor to abandonment and a lack of incentive to farm among the youth, among other drivers of cropland abandonment.

Du et al. [12] explored the association of cropland abandonment and farmers' access to agricultural credit in China by using systematic surveys of 8031 households from 27 provinces and Tobit regression models. The study showed the importance of formal and informal credits to suppress or avoid a decision about abandonment. Abandonment was also associated with remote areas, steep slopes, senior-aged farmers and a lack of successors. 
Kumm and Hessle [13] looked at the economy of alternative options to abandonment and common re-use of abandoned lands for spruce plantations in Sweden. By making calculations for forest districts of northern, central and southern Sweden, they envisioned the alternatives, notably organic beef production with a herd of a certain size.

Kuntz et al. [14] looked at the ongoing afforestation and change of the composition of rural landscapes from the lens of perceptions of local farmers in New York State in the United States. For this purpose, they utilized questionnaires with qualitative and quantitative questions. The answers pointed toward a generally negative perception of abandonment, especially among full-time farmers and Republicans.

Funding: We thank DFF-Danish ERC Support Program (grant number: 116491, 9127-00001B), as well as EU FP7 ERA.Net Russia Plus (grant number: 449 CLIMASTEPPE). Special issue contributes to the Global Land Programme (GLP.earth) and more specifically to the activity of GLP's working group "Agricultural land abandonment as a global land-use change process". The SI also is the outcome of the session Agricultural land abandonment in the teleconnected world" during the 4th GLP Open Science Meeting, 24-26 April 2019, which took place in Bern, Switzerland.

Institutional Review Board Statement: Not applicable.

Informed Consent Statement: Not applicable.

Conflicts of Interest: The SI editors declare no conflict of interest.

\section{References}

1. Huang, Y.; Li, F.; Xie, H. A Scientometrics Review on Farmland Abandonment Research. Land 2020, 9, 263. [CrossRef]

2. Queiroz, C.; Beilin, R.; Folke, C.; Lindborg, R. Farmland Abandonment: Threat or Opportunity for Biodiversity Conservation? A Global Review. Front. Ecol. Environ. 2014, 12, 288-296. [CrossRef]

3. Renwick, A.; Jansson, T.; Verburg, P.H.; Revoredo-Giha, C.; Britz, W.; Gocht, A.; McCracken, D. Policy Reform and Agricultural Land Abandonment in the EU. Land Use Policy 2013, 30, 446-457. [CrossRef]

4. Chaudhary, S.; Wang, Y.; Dixit, A.M.; Khanal, N.R.; Xu, P.; Fu, B.; Yan, K.; Liu, Q.; Lu, Y.; Li, M. A Synopsis of Farmland Abandonment and Its Driving Factors in Nepal. Land 2020, 9, 84. [CrossRef]

5. Holcomb, J.P.; Frederic, P.; Brunn, S.D. A Visual Typology of Abandonment in Rural America: From End-of-Life to Treading Water, Recycling, Renaissance, and Revival. Land 2020, 9, 94. [CrossRef]

6. Pazúr, R.; Lieskovský, J.; Bürgi, M.; Müller, D.; Lieskovský, T.; Zhang, Z.; Prishchepov, A.V. Abandonment and Recultivation of Agricultural Lands in Slovakia-Patterns and Determinants from the Past to the Future. Land 2020, 9, 316. [CrossRef]

7. Kolecka, N.; Kozak, J. Wall-to-Wall Parcel-Level Mapping of Agricultural Land Abandonment in the Polish Carpathians. Land 2019, 8, 129. [CrossRef]

8. Huang, X.; Ziniti, B.; Torbick, N. Assessing Conflict Driven Food Security in Rakhine, Myanmar with Multisource Imagery. Land 2019, 8, 95. [CrossRef]

9. Kc, B.; Race, D. Outmigration and Land-Use Change: A Case Study from the Middle Hills of Nepal. Land 2019, 9, 2. [CrossRef]

10. Chaudhary, S.; Wang, Y.; Dixit, A.M.; Khanal, N.R.; Xu, P.; Fu, B.; Yan, K.; Liu, Q.; Lu, Y.; Li, M. Spatiotemporal Degradation of Abandoned Farmland and Associated Eco-Environmental Risks in the High Mountains of the Nepalese Himalayas. Land 2019, 9, 1. [CrossRef]

11. Blair, D.; Shackleton, C.; Mograbi, P. Cropland Abandonment in South African Smallholder Communal Lands: Land Cover Change (1950-2010) and Farmer Perceptions of Contributing Factors. Land 2018, 7, 121. [CrossRef]

12. Du, J.; Zeng, M.; Xie, Z.; Wang, S. Power of Agricultural Credit in Farmland Abandonment: Evidence from Rural China. Land 2019, 8, 184. [CrossRef]

13. Kumm, K.-I.; Hessle, A. Economic Comparison between Pasture-Based Beef Production and Afforestation of Abandoned Land in Swedish Forest Districts. Land 2020, 9, 42. [CrossRef]

14. Kuntz, K.; Beaudry, F.; Porter, K. Farmers' Perceptions of Agricultural Land Abandonment in Rural Western New York State. Land 2018, 7, 128. [CrossRef]

15. Van Vliet, J.; de Groot, H.L.F.; Rietveld, P.; Verburg, P.H. Manifestations and Underlying Drivers of Agricultural Land Use Change in Europe. Landsc. Urban Plan. 2015, 133, 24-36. [CrossRef]

16. Hatna, E.; Bakker, M.M. Abandonment and Expansion of Arable Land in Europe. Ecosystems 2011, 14, 720-731. [CrossRef]

17. Prishchepov, A.V.; Müller, D.; Dubinin, M.; Baumann, M.; Radeloff, V.C. Determinants of Agricultural Land Abandonment in Post-Soviet European Russia. Land Use Policy 2013, 30, 873-884. [CrossRef]

18. Schierhorn, F.; Müller, D.; Beringer, T.; Prishchepov, A.V.; Kuemmerle, T.; Balmann, A. Post-Soviet Cropland Abandonment and Carbon Sequestration in European Russia, Ukraine, and Belarus. Glob. Biogeochem. Cycles 2013, 27, 1175-1185. [CrossRef]

19. Löw, F.; Prishchepov, A.; Waldner, F.; Dubovyk, O.; Akramkhanov, A.; Biradar, C.; Lamers, J. Mapping Cropland Abandonment in the Aral Sea Basin with MODIS Time Series. Remote Sens. 2018, 10, 159. [CrossRef] 
20. Shackleton, C.M.; Mograbi, P.J.; Drimie, S.; Fay, D.; Hebinck, P.; Hoffman, M.T.; Maciejewski, K.; Twine, W. Deactivation of Field Cultivation in Communal Areas of South Africa: Patterns, Drivers and Socio-Economic and Ecological Consequences. Land Use Policy 2019, 82, 686-699. [CrossRef]

21. Xie, H.; Wang, P.; Yao, G. Exploring the Dynamic Mechanisms of Farmland Abandonment Based on a Spatially Explicit Economic Model for Environmental Sustainability: A Case Study in Jiangxi Province, China. Sustainability 2014, 6, 1260. [CrossRef]

22. Davis, M.A.; Reich, P.B.; Knoll, M.J.B.; Dooley, L.; Hundtoft, M.; Attleson, I. Elevated Atmospheric CO2: A Nurse Plant Substitute for Oak Seedlings Establishing in Old Fields. Glob. Chang. Biol. 2007, 13, 2308-2316. [CrossRef]

23. Christensen, V.G.; Lee, K.E.; McLees, J.M.; Niemela, S.L. Relations between Retired Agricultural Land, Water Quality, and Aquatic-Community Health, Minnesota River Basin. J. Environ. Qual. 2012, 41, 1459-1472. [CrossRef] [PubMed]

24. Kalinina, O.; Goryachkin, S.V.; Karavaeva, N.A.; Lyuri, D.I.; Najdenko, L.; Giani, L. Self-Restoration of Post-Agrogenic Sandy Soils in the Southern Taiga of Russia: Soil Development, Nutrient Status, and Carbon Dynamics. Geoderma 2009, 152, 35-42. [CrossRef]

25. Kurganova, I.; Lopes de Gerenyu, V.; Kuzyakov, Y. Large-Scale Carbon Sequestration in Post-Agrogenic Ecosystems in Russia and Kazakhstan. Catena 2015, 133, 461-466. [CrossRef]

26. FAOSTAT Food and Agriculture Organization of the United Nations. FAOSTAT Database. Trade. Crops and Livestock Products. Available online: http:/ / faostat3.fao.org/browse/T/TP/E (accessed on 20 January 2020).

27. Prishchepov, A.V. Agricultural Land Abandonment. In Environmental Science; Oxford Bibliographies: Oxford, UK, 2020. [CrossRef]

28. Hebinck, P.; Mtati, N.; Shackleton, C. More than Just Fields: Reframing Deagrarianisation in Landscapes and Livelihoods. J. Rural Stud. 2018, 61, 323-334. [CrossRef]

29. UN FAO. The Role of Agriculture and Rural Development in Revitalizing Abandoned/Depopulated Areas; Food and Agriculture Organization of the United Nations: Rome, Italy, 2006; p. 24.

30. UN FAO. FAOSTAT, Methods E Standards [WWW Document]; Food and Agriculture Organization of the United Nations: Rome, Italy, 2016; p. 3.

31. Grădinaru, S.R.; Iojă, C.I.; Vânău, G.O.; Onose, D.A. Multi-Dimensionality of Land Transformations: From Definition to Perspectives on Land Abandonment. Carpathian J. Earth Environ. Sci. 2020, 15, 167-177. [CrossRef]

32. Geist, H.J.; Lambin, E.F. Proximate Causes and Underlying Driving Forces of Tropical Deforestation. Bioscience 2002, 52, 143-150. [CrossRef]

33. Baumann, M.; Kuemmerle, T. The Impacts of Warfare and Armed Conflict on Land Systems. J. Land Use Sci. 2016, 11, 672-688. [CrossRef]

34. Maystadt, J.-F.; Mueller, V.; Van Den Hoek, J.; van Weezel, S. Vegetation Changes Attributable to Refugees in Africa Coincide with Agricultural Deforestation. Environ. Res. Lett. 2020, 15, 044008. [CrossRef]

35. Eklund, L.; Degerald, M.; Brandt, M.; Prishchepov, A.V.; Pilesjö, P. How Conflict Affects Land Use: Agricultural Activity in Areas Seized by the Islamic State. Environ. Res. Lett. 2017, 12, 054004. [CrossRef]

36. Yin, H.; Butsic, V.; Buchner, J.; Kuemmerle, T.; Prishchepov, A.V.; Baumann, M.; Bragina, E.V.; Sayadyan, H.; Radeloff, V.C. Agricultural Abandonment and Re-Cultivation during and after the Chechen Wars in the Northern Caucasus. Glob. Environ. Chang. 2019, 55, 149-159. [CrossRef]

37. Hostert, P.; Kuemmerle, T.; Prishchepov, A.; Sieber, A.; Lambin, E.F.; Radeloff, V.C. Rapid Land Use Change after Socio-Economic Disturbances: The Collapse of the Soviet Union versus Chernobyl. Environ. Res. Lett. 2011, 6, 045201. [CrossRef]

38. Sekizawa, R.; Ichii, K.; Kondo, M. Satellite-Based Detection of Evacuation-Induced Land Cover Changes Following the Fukushima Daiichi Nuclear Disaster. Remote Sens. Lett. 2015, 6, 824-833. [CrossRef]

39. Prishchepov, A.V.; Radeloff, V.C.; Baumann, M.; Kuemmerle, T.; Müller, D. Effects of Institutional Changes on Land Use: Agricultural Land Abandonment during the Transition from State-Command to Market-Driven Economies in Post-Soviet Eastern Europe. Environ. Res. Lett. 2012, 7, 024021. [CrossRef]

40. Munroe, D.K.; van Berkel, D.B.; Verburg, P.H.; Olson, J.L. Alternative Trajectories of Land Abandonment: Causes, Consequences and Research Challenges. Curr. Opin. Environ. Sustain. 2013, 5, 471-476. [CrossRef] 